\title{
On The Impact Of Family Versus Institutional Blockholders On Dividend Policy
}

Raoudha Djebali, University of Tunis, Tunisia

Amel Belanès, University of Tunis, Tunisia

\begin{abstract}
This paper investigates the effect of not only the controlling shareholders but also their identity on dividend policy. For a large panel of French firms during the period 2006-2010, we find that the dividend payout ratio increases with the ownership concentration. However, this result changes with the identity of the largest shareholder. Family-controlled firms are more tempted to distribute lower dividends while firms dominated by institutional investors likely distribute higher dividends. Empirical results also reveal that firms with more independent directors are associated with higher dividend payout in contrast to US cross-listed firms.
\end{abstract}

Keywords: Corporate Governance; Dividend Policy; Blockholders; Family Firms; Institutional Investors

\section{INTRODUCTION}

ince the classic work of Lintner (1956), many researchers and scholars have attempted to resolve the dividend puzzle. Previous literature has offered a variety of explanations for dividend policy mainly based on tax clienteles, signaling concern and agency conflicts. Consistent with agency hypotheses, dividends are argued to mitigate agency conflicts by reducing the free cash flow that managers may divert for personal objective or to pursue unprofitable investment opportunities (Jensen, 1986). In this vein, dividends typically deal with interest conflicts between inside managers and outside shareholders rather than those between minority and majority shareholders. A large body of previous research has focused on common-law countries such as the US or UK where the ownership is mainly dispersed and the laws are strong enough to protect shareholders rights. In this context, the main agency problem is between managers and outsides shareholders and dividends can mitigate such a problem.

In contrast, in civil-law countries ownership is much more concentrated and law requirements for management are rather weak (La Porta et al., 1999). Salient features of the corporate governance system in these countries involve the discrepancy between voting and cash flow rights due to pyramiding, cross-holdings, and large controlling stakes of families, institutional investors, and the state. Since the control is concentrated in the hands of a few owners, the most prominent agency conflict is not the one between managers and shareholders but rather between blockholders and minority shareholders (Holderness \& Sheehan, 1988; Barclay \& Holderness, 1989; Shleifer \& Vishny, 1997).

For instance, blockholders often have managerial ties; which likely allows them to prioritize their interests at the expense of other shareholders. Recent empirical evidence has emphasized a wide range of schemes used by dominant shareholders to extract private benefits at the expense of minority shareholders including the tunneling of assets and profits, the use of unfair transfer pricing between controlled entities (Bebchuk et al., 1999; Claessens et al., 2000; Johnson et al., 2000; Faccio et al., 2001). Given that the structure of capital markets and governance systems are different, the determinants of key corporate decisions including dividend policy are likely to differ as well. Dividends are believed to be an outcome of the legal shareholder protection and to play a governance role in common-law countries whereas in civil-law ones they are argued to substitute for governance problems 
(Easterbrook, 1984; Gomes, 2000). Perhaps, deviations from the one-share-one-vote rule in the latter may lead to negative wealth effects and thus lower pay-out ratios while minority shareholders in the former would likely force the manager to distribute higher dividends thanks to the law enforcement (La Porta et al., 2000).

In this paper, we present evidence consistent with one of the agency conflict explanations of dividends that stem from the separation of control and ownership. We particularly investigate whether differences in ownership structure and owners identity across firms, within a civil-law country, can explain their dividend payout differences. Using a large sample of French firms over 2006-2010, we attempt to answer the following questions: how do controlling shareholders influence dividend policy? Does their identity matter in this corporate decision?

This study makes three main contributions. First, it offers a number of insights into both dividend policy and rent expropriation in the context of civil-law countries. Second, we focus on the effect of not only the controlling shareholders but also their identity on dividend. There is a little empirical evidence that shows that dividend policy depends on the type of the ultimate blockholder. Third, most previous research in French context focused on institutional and managerial ownership in presence of majority shareholders (Boys, 2009; Said, 2013) or on the insider ownership in very broad terms (Farinha \& De Foronda, 2009). Other studies explored the relationship between dividend policy and leverage in holding companies (Boys, 2009; De Jong et al., 2010). This study wants to shed some light in this issue by comparing the impact of the family and institutional blockholders on the payout within French firms. These firms exhibit a variation across identities of controlling owners; what makes them an ideal pattern for analyzing the influence of the identity of dominant investors on dividend policy.

The following section reviews the background literature and develops the hypotheses. Section 3 describes the sample and the methodology. Empirical results are presented and discussed in Section 4. Section 5 concludes with implications and suggestions for future research.

\section{BACKGROUND LITERATURE}

\subsection{On the Influence Of Ownership Concentration on Dividend Policy}

Empirical research on the effect of ownership concentration on dividend provides mixed results. Two opposite hypotheses can be hereafter developed regarding the impact of ownership concentration on dividend policy.

One hypothesis argues that dividends can be an ideal tool to mitigate agency problems and to reinforce management monitoring. Indeed, payment of dividends enables reducing free cash flows and discretionary funds available to managers (Rozeff, 1982; Easterbrook, 1984; Jensen, 1986). This hypothesis can be applied to dispersedownership firms where the traditional agency problem is the conflict between managers and shareholders, consistent with the paradigm of Berle and Means (1932). But also, this hypothesis can be applied to highly concentratedownership firms where the attendant agency problem is the expropriation of minority shareholders by large ones due to the rise of the "law and finance" paradigm. In fact, the two kinds of problems likely coexist in such concentratedownership firms. For instance, in France, some previous studies report that payout can be used to regulate conflicts between managers and shareholders but not between large and small investors, to reduce the risk of free cash flow either (Boys, 2009). Other studies support the negative effect of managerial ownership versus the positive impact of the controlling shareholders on dividends (Said, 2013). Several studies document that strong investor protection laws within this context urge firms to disgorge cash and to pay dividends in order to curtail, to some extent, expropriation by insiders, even though the major agency conflict is between dominant and minority shareholders rather than shareholders and managers (Faccio et al., 2001; Thomsen, 2005; Kalcheva \& Lins, 2007; Brockman and Unlu, 2009). Perhaps, in firms with majority shareholders, such as in France, these conflicts are expected to be lower since the controlling shareholders have a stronger incentive to monitor managers. Given that blockholders are more concerned with corporate governance and better positioned to benefit from this disciplinary device, ownership concentration is expected to have a positive influence on dividend payout.

Furthermore, controlling shareholders are prone to induce managers to distribute higher dividends to divulge their reluctance to expropriate minority investors, which is in line with the rent extraction property of dividends (Gugler \& Yurtoglu, 2003). For instance, majority shareholders are tempted to build up a reputation of 
treating minority shareholders well (Gomes, 2000). Such a behavior can hide an acute problem of wealth expropriation and asset tunneling. In this vein, the use of leverage in pyramidal structures and holding companies is believed to broaden the disparity between control rights and cash flow rights, and thus more agency conflicts are pronounced between majority and minority shareholders. In the meantime, higher dividends are reported as they are needed to repay back the debt in the holding companies (De Jong et al., 2010). The positive effect of ownership concentration on dividend should be then more relevant in countries where shareholder rights are neither well protected nor very developed (La Porta et al., 2000). This positive effect of ownership concentration on dividend is also consistent when managers follow a "sleeping dogs" approach to payouts (Warther, 1993). Accordingly, managers tend to pay out just enough dividends to avoid conflicts with shareholders irrespective of their identity, and thus please both minority shareholders and the controlling family and keep them satisfied (Zwiebel, 1996; Myers, 2000). Managers are willing to distribute higher dividends so as to be less monitored in return.

The alternative hypothesis assumes that controlling blockholders are tempted to expropriate private benefits at the expense of other shareholders, consistent with the rent extraction hypothesis (Grossman and Hart, 1988; Barclay and Holderness, 1989; Bebchuk et al., 1999). Dominant shareholders are eager to solely consume corporate resources under their control, especially in countries where legal protection of shareholders interests is poor or not strong enough (Shleifer \& Vishny, 1997; La Porta et al., 1999). They would therefore use their voting power to urge managers to distribute lower dividends; which contributes to wealth extraction and expropriation at the expense of minority shareholders. Their preference to pay lower dividends is driven by their willingness to reduce shared benefits namely dividends so as to safeguard and enlarge their private benefits. Accordingly, dominant shareholders are prone to accumulate higher private benefits so that it remains little benefits to be shared with other shareholders, and thus lower dividend (Shleifer \& Vishny, 1997; Facio et al., 2000; Johnson et al., 2000; Dyck \& Zingales, 2004; Renneboog \& Trojanowski, 2005; Luciana \& Aydin, 2006; Khan, 2006). Even though when the funds increase thanks to a rise in earnings or leverage, concentrated-ownership firms are reluctant to raise dividends (Harada \& Nguyen, 2011). Higher ownership concentration is thus expected to be associated with lower dividends.

However, the impact of multiple controlling shareholders on the dividend policy is not obvious; especially that related empirical evidence has been limited. The presence of another large shareholder may either exacerbate or mitigate the conflicts of interest according to the context and the firm specificities (Faccio et al., 2001). On one hand, controlling shareholders can collude in expropriating corporate resources and sharing the private benefits at the expense of outside shareholders (Pagano \& Roell, 1998; Faccio et al., 2001; Maury \& Pajuste, 2002). Because of this acute problem of rent protection, their preference should tilt towards lower payouts. On the other hand, the existence of other large blockholders may contribute to a mutual supervising and to enhance corporate governance (Gugler \& Yurtoglu, 2003; Ramli, 2010). Given that mutual monitoring would curb this tendency to expropriate private benefits, higher dividend payouts can be offered for all shareholders irrespective of their type.

\subsection{On the Effect of Blockholder Identity on Dividend Policy}

There is a little empirical evidence that highlights that the type of the controlling owner is likely to influence corporate decisions namely dividend policy (Gugler, 2003). For instance, some types of controlling shareholders are expected to have more power to expropriate minority shareholders, which might contribute in lower dividends (Maury \& Pajuste, 2002). Given that French firms are dominated by families and institutional investors, we aim to separately analyze the impact of each type of blockholders on dividend policy.

The divergence of interests between majority and minority shareholders can be an ultimate issue in family firms. Agency problems with blockholders are even more severe for family owners as compared to other shareholders (Cronqvist and Nilsson, 2003). Indeed, the position of the controlling family enables it to promote ideas or projects that benefit its own personal preferences rather than the whole firm; what might harm the interests of minority shareholders. For instance, it might lead to the misuse of firm funds, and hence the decline of dividends (Isakov and Weisskop, 2015). But also, family owners would rather reinvest excess cash-flows to maximize longterm revenues and guarantee the survival of the firm for future generations. This mainly stems from the fear to squander a multiple-generation-family wealth and jeopardize the family name and reputation (Bartholomeusz and Tanewski, 2006). Firms controlled by private owners are hence argued to have lower dividend levels. They are even more likely to cut dividends when necessary; even though they are less reluctant to do it than state-controlled firms 
(Gugler, 2003). Furthermore, firms with a controlling family tend to pay lower dividends since the conflicts of interest and asymmetry of information are expected to be less acute between the manager and the controlling family; and dividends are thus less valuable as a governance device. Indeed, in family-controlled firms, the management is often part of the controlling family and the residual claimants would bear all the costs and similarly receive all benefits (Claessens et al., 2000). If the manager does not belong to the family group, the large family shareholders have enough incentives and the ability to efficiently monitor the management. In both cases, family-controlled firms tend to pay lower dividends because of lower agency problems.

However, the controlling family may prefer larger payouts even in the absence of effective governance mechanisms. This policy can be motivated by at least two incentives: reputation building and family income needs (Isakov and Weisskop, 2015). First, the controlling family is eager to build a good reputation and may therefore commit not to expropriate minority shareholders and to payout higher dividends instead (Gomes, 2000). This is consistent with the "substitution model" of La Porta et al. (2000) according to which insiders likely offer larger payouts, especially before an issuance of equity. This may happen whether the firm is managed by an outside CEO or the controlling family is actively involved in the firm management mainly through the board of directors (Isakov and Weisskop, 2015). Even an outside CEO has to reconcile between his own benefits and those of the family members and to set up the right balance (DeAngelo \& DeAngelo, 2000). The CEO tends to pay higher dividends to bear less control in return. Second, family members might prefer larger dividends to satisfy their income needs since most of their wealth is invested in the firm and want to lock on the control of the firm for the long run (Isakov and Weisskop, 2015). For instance, they cannot sell shares either to diversify their wealth or to finance their needs. This tendency to pay higher dividends would increase with older firms and those having more family members involved.

Predictions about dividend policy in firms controlled by institutional investors are also confusing. Some studies report no significant influence of institutional ownership on dividend (Zeckhauser \& Pound, 1990; Said, 2013) while others put in evidence a significant effect. On the one hand, institutional investors are believed to contribute to alleviating agency problems and guaranteeing achievement of all shareholders interests (McConnell \& Servaes, 1990; Jensen et al., 1992; Short et al., 2002). They are also renowned to lessen asymmetry of information and liquidity constraints (Hoshi et al., 1990). They can particularly reduce agency conflicts associated with excess free cash flow (Karpavicius \& Yu, 2012) in addition to higher debt (Jensen, 1986). Consistent with agency theory argument, several studies argue the positive influence of the share of capital held by institutional investors, especially those external, on dividends (Bhagat \& Jefferis, 2002; Bravet al., 2005; Wang and Scott, 2011). This is namely due to their great material resources, sophisticated skills and extended networks (Gillan \& Starks, 2007). Tax preferences of institutional investors in favor of dividend income may also explain the positive relationship between large institutional shareholdings and dividends (Short et al., 2002). Given the dominant presence of institutional investors, other blockholders are less tempted to extract private benefits; what might lead to higher dividends. That is institutional blockholders are expected to positively influence the payout.

On the other hand, firms controlled by institutional investors are claimed to favor lower and not necessarily smoothing dividend payments in order to better shield their debt from bankruptcy risks (Amihud and Murgia, 1997) and satisfy the solvency requirements which become increasingly more binding. Smoothing of dividends is only marginally important in firms controlled by institutional investors, especially that they have other means than dividends to curb agency costs, for instance, interest payments on debt (Gugler, 2003). Institutional Shareholders are therefore expected to have a negative impact on the dividend payout (Maury \& Pajuste, 2002). Similarly, the largest institutional shareholder is likely to have a negative impact on the dividend. Indeed, the most dominant institutional investor is believed to substitute dividend distribution thanks to its signaling power; which is in line with the signaling theory (Renneboog \& Trojanowski, 2005).

Nonetheless, the dividend policy is also influenced by the financial specificities of the firm especially the investment opportunities set and the leverage; whatever is the identity of the controlling owner. For instance, firms with bad growth prospects tend to pay higher dividends while those with better investment opportunities are rather reluctant to pay out dividend or at least delay their payments. In the first case, this would presumably happen as a response to the pressure of outside shareholders. In the second case, disgorging internal cash flows would be less expensive than external debt to finance potential investment projects. These findings are often valid irrespective of who controls the firm (Gugler, 2003). This is consistent with the signaling hypotheses of Battacharya (1979) and 
Fama and French (2002). Besides, highly-levered firms likely pay lower dividends in order to meet their financial commitments (Jensen et al., 1992; Gugler and Yortuglu, 2003; Truong \& Heaney, 2007). Furthermore, preferences of family and institutional investors for dividend income likely depend on differential taxation on dividend income and capital gains between them (Short et al., 2002). The hypothesis of clientele effects presumes that investors are eager to pick up firms that most suit their tax status/income needs. However, most studies overlook this important consideration since it is necessary to disaggregate the whole shareholding to disentangle the tax incentives of institutional and family investors. Even those that try to highlight these tax considerations are unable to do that and hence lead to biased results (Khan, 2006). Other studies recognize that tax considerations or tax clientele effects cannot drive cross-sectional differences in dividend policy whereas most persuasive incentives are based on agency considerations (Khan, 2006; Bena \& Hanousek, 2008; Denis \& Osobov, 2008).

\section{DATA AND METHODOLOGY}

\subsection{Data and Sample}

Our sample is made up of 110 French listed firms which belong to the SBF250 (Société des Bourses Françaises 250 index) during the period 2006-2010. SBF250 is a stock market index that includes all sectors of the French economy. About $15 \%$ of these firms are also listed on a US Stock Exchange. Industrial firms represent $47.5 \%$ of the sample while $52.5 \%$ of the firms operate in the fields of trade and services. All regulated firms, such as financial institutions, banks and insurance companies are eliminated. Firms with missing date are also excluded. Data on the ownership structure, corporate governance, dividend payout ratio and financial statements have all been manually collected from the website of the AMF (Autorités des Marchés Financiers); otherwise, we resort to firms' annual reports displayed in their relative websites.

\subsection{Econometric Modeling}

Table 1 defines the variables included in our models. The dividend payout ratio (DPR) is the cash dividend per share divided by earnings per share as measured by Mitton (2005), Adjaoud and Ben Amar (2010) among others. There are two variables to reveal the ownership concentration: CONC and MULT. CONC is the percent of shares owned by the three largest shareholders and is used as a proxy for ownership concentration (Dyck \& Zingales, 2004; La Porta et al., 1999). Block ownership can either contribute to intensify or reduce agency conflicts. Therefore, ownership concentration can be associated with either higher dividend (Rozeff, 1982; Easterbrook, 1984; Jensen, 1986) or lower dividends (Johnson et al., 2000; Dyck \& Zingales, 2004). MULT is a dummy variable that accounts for the presence of another blockholder which may either exacerbate the conflicts of interest between controlling and minority shareholders (Pagano \& Roell, 1998; Faccio et al., 2001; Maury \& Pajuste, 2002) or mitigate them (Gugler \& Yurtoglu, 2003; Ramli, 2010).

Table 1. Variables definition

\begin{tabular}{ll}
\hline Ownership Concentration \\
\hline CONC & $\%$ of shareholding of the first three blockholders \\
DVR & $\%$ of firms with double voting rights \\
FAML & dummy variable $=1$ if the largest shareholder is a family \\
INST & dummy variable $=1$ if the largest shareholder is an institution \\
\hline Corporate Governance & dummy variable $=1$ for firms with another blockholder with at least $10 \%$ of the voting rights \\
\hline MULT & $\%$ of independent directors within the board \\
NDIR & dummy variable $=1$ if the firm is listed on a US market \\
CRSL & dividend to earnings per share \\
\hline Financial Characteristics \\
\hline DPR & total assets on log scale \\
SIZE & total debt to total assets \\
LEV & operating income to total assets \\
ROA & market-to-book ratio \\
OPP &
\end{tabular}


Besides, two corporate governance variables are included, namely the percentage of independent directors (NDIR) and cross-listing in the US (CRSL). NDIR is defined as the percentage of independent directors. CRSL is a dichotomous variable that checks whether the firm is cross-listed in the US. Many empirical studies find a positive relationship between payout and the percent of independents directors (Sharma, 2011; Mitton, 2005). However, a negative relationship is reported between US cross-listing and dividend (Adjaoud \& Ben Amar, 2010). In addition, four variables are considered to highlight financial specificities, namely size, profitability, leverage and growth opportunities. Firm size (SIZE) is measured by total assets on log scale. Large firms are more mature and have higher free cash flows than small peers, and can consequently pay higher dividends (Fama \& French, 2002). Profitability (ROA), the return on assets ratio, is expected to have a positive impact on dividend (Jensen et al., 1992; Fama and French, 2002; Truong and Heaney, 2007). Leverage (LEV) is assessed through the ratio of total liabilities to total assets. Highly-levered firms are financially constrained and should be less able to pay dividends (Fama \& French, 2002; Jensen et al., 1992). Growth opportunities (OPP) are approximated by the market-to-book ratio and are believed to negatively influence dividends because of the need to fund future investments (Fama \& French, 2002; Mitton, 2005).

To analyze the effect of block ownership on dividend payout, we estimate the following model (1):

$D P R_{i t}=\beta_{0}+\beta_{1} C O N C_{l t}+\beta_{2} M U L T_{i t}+\beta_{3} C R S L_{i t}+\beta_{4} N D I R_{i t}+\beta_{5} S I Z E_{i t}+\beta_{6} R O A_{i t}+\beta_{7} L E V_{i t}+\beta_{8} O P P_{i t}+\varepsilon_{l i}$

Following Farinha \& De Foronda (2009), we investigate whether the relationship between ownership concentration and dividends is non linear. Accordingly, as insider ownership grows, dividends first increase, then fall after a certain threshold, and finally increase once again. Payouts first increase with an increase in insider ownership until a critical level of $46 \%$ ownership; what reveals an alignment of interests between majority and minority shareholders. The relationship turns after into negative; consistent with entrenchment effect and tunneling hypothesis. Such a relationship reveals an acute problem of rent expropriation of large shareholders at the expense of minority peers. This is mainly specific for shareholders with levels of participation at around half of total shares. When insider ownership rises above the threshold of $77 \%$, the influence of insider ownership on dividends becomes then positive because of the liquidity needs faced by ultimate blockholders. Farinha and De Foronda (2009) analyze the influence of ownership on dividend while our study focuses on the effect of ownership concentration on payout. Therefore, we would consider the non linear relationship rather than the cubic one. The model (2) sets as follows:

$$
\begin{gathered}
D P R_{i t}=\alpha_{0}+\alpha_{1} \operatorname{CONC}_{l t}+\alpha_{2} \operatorname{CONC}_{i t}^{2}+\alpha_{3} M U L T_{i t}+\alpha_{4} \operatorname{CRSL}_{i t}+\alpha_{5} N D I R_{i t}+\alpha_{6} S I Z E_{i t}+\alpha_{7} R O A_{i t}+\alpha_{8} L E V_{i t} \\
+\alpha_{9} O P P_{i t}+\epsilon_{l i}
\end{gathered}
$$

\section{RESULTS AND DISCUSSIONS}

\subsection{Descriptive Statistics and Univariate Analysis}

Table 2 summarizes descriptive statistics regarding ownership concentration, corporate governance as well as financial characteristics, including the dividend payout ratio. Table 2 highlights that the three largest shareholders hold on average $44.4 \%$ and sometimes the whole capital; what puts in evidence the concentrated ownership of most French firms mainly due to pyramiding and cross-holdings. For instance, more than $74.03 \%$ of firms offer double voting rights to their shareholders and about $30.87 \%$ of firms have a second blockholder with at least $10 \%$ of the voting rights. But above all, the first blockholder on average holds $32.6 \%$ of total equity while the second blockholder detains around $10.2 \%$ of the capital. The average shareholding of the third blockholder does not exceed $3.38 \%$ of the whole equity but can sometimes reach $21.1 \%$. That's why we only focus on the shares hold by the three majority shareholders to proxy ownership concentration in French firms. Table 2 also reports that about $63 \%$ of firms have a family blockholder whereas the most dominant investor in $35 \%$ of them is institutional.

Table 2 displays some statistics relative to other corporate governance characteristics, namely board of directors and cross-listing. The boards of French firms are not entirely made up of independent directors. The latter represents only $37.67 \%$ of the whole number but in some cases reaches $100 \%$. Furthermore, $15 \%$ of French firms

are listed on an American stock exchange; what implies that these firms must comply with better standards of corporate governance and tough requirements of the SEC in the US. When they are cross-listed on a U.S. exchange, 
firms should bear direct constraints pertaining to laws, disclosures, and enforcement actions as well as indirect constraints due to the increasing scrutiny of "gatekeepers" such as analysts and the media (Stulz, 1999). These constraints likely deter controlling shareholders from extracting private benefits.

Table 2. Descriptive Statistics

\begin{tabular}{|c|c|c|c|c|c|}
\hline Variables & Freq & Mean & Min & Max & S.D \\
\hline \multicolumn{6}{|l|}{ Ownership Concentration } \\
\hline$\%$ of capital of the first blockholder & & 0.3263 & 0.0173 & 0.999 & 0.2214 \\
\hline$\%$ of capital of the second blockholder & & 0.1020 & 0.000 & 0.488 & 0.0954 \\
\hline$\%$ of capital of the third blockholder & & 0.03378 & 0.000 & 0.211 & 0.0395 \\
\hline CONC & & 0.444 & 0.02 & 0.999 & 0.243 \\
\hline DVR & $74.03 \%$ & & & & \\
\hline FAML & $63 \%$ & & & & \\
\hline INST & $35 \%$ & & & & \\
\hline \multicolumn{6}{|l|}{ Corporate Governance Characteristics } \\
\hline MULT & $30.87 \%$ & & & & \\
\hline NDIR & & 0.3767 & 0.000 & 1 & 0.2474 \\
\hline CRSL & $15 \%$ & & & & \\
\hline \multicolumn{6}{|l|}{ Financial Characteristics } \\
\hline DPR & & 0.271 & 0 & 4.53 & 0.7081 \\
\hline SIZE & & 14.13 & 7.6 & 19.003 & 2.109 \\
\hline LEV & & 0.563 & 0.040 & 1.3 & 0.1969 \\
\hline ROA & & 0.066 & -0.7 & 0.6 & 0.0918 \\
\hline OPP & & 2.860 & 0.180 & 12.87 & 3.619 \\
\hline
\end{tabular}

Variable Definitions: See Table 1 except SIZE (total assets in millions of Euros).

Table 2 also shows that French listed firms distribute around the third of their net incomes as dividends. Such statistics are slightly close to those reported in other studies carried out in France (Truong and Heaney, 2007). According to Table 2, there are some firms that do not pay any dividend (Minimum $=0$ ) while others seem to cumulate dividends of many years and distribute all of them when it is suitable to do it (Maximum $=4.53$ ). Table 2 finally puts in evidence that French firms are highly indebted with an average ratio of leverage of 0.563 and little profitable with an average ROA of 0.066. However, they are quite appealing to investors as their market capitalization is around 2.86 times the book value. While further investigating the average dividend payout across French firms, we find that it depends on the identity of the first blockholder, on the presence of another blockholder and whether the firm is listed on a US market. Table 3 puts in evidence that firms which the largest shareholder either belongs to a family group or is not an institutional investor distribute lower dividends than their peers. Besides, the presence of multiple large shareholders contributes to reducing the dividend payout and so does the listing of the firm on a US stock exchange.

Table 3. Dividend payout analysis

\begin{tabular}{lcc|c}
\hline \multicolumn{1}{c|}{ Identity of the largest shareholder } & DPR mean & t-test of means \\
\hline Family vs non-family & 0.1689 & 0.3369 & $\begin{array}{c}2.974^{*} \\
(0.001)\end{array}$ \\
\hline Institutional vs non-institutional investor & 0.3574 & 0.1924 & $\begin{array}{c}-3.289^{*} \\
(0.00)\end{array}$ \\
\hline There is another blockholder vs non & 0.1935 & 0.3069 & $\begin{array}{c}1.8054^{*} \\
(0.035)\end{array}$ \\
\hline US cross-listed firm vs non & 0.1939 & 0.2865 & $\begin{array}{c}1.986^{*} \\
(0.02)\end{array}$ \\
\hline
\end{tabular}

\subsection{Ownership Concentration and Dividend Policy}

Table 4 reports empirical results relative to the influence of block ownership on the dividend payout for two panels: the first takes into account the governance role of directors (Panel 1) while the second the mutual supervision of large shareholders (Panel 2). Panel 3 in Table 4 presents results associated with the non linear relationship between dividends and ownership concentration. Both of them are internal corporate governance 
devices. In both cases, Table 4 puts in evidence a positive and a significant impact of ownership concentration; which implies that firms dominated by large shareholders are tempted to pay higher dividends. Such a finding emphasizes the effective governance role of large shareholders who play a great role in reducing managerial opportunism and in protecting shareholders' rights irrespective of their identity. This result is in line with those of Truong and Heaney (2007) and Said (2013) but in contrast with Khan (2006) and Boys (2009). It does not support the hypothesis of wealth expropriation by dominant shareholders at the expense of minority ones.

Following Farinha and De Foronda (2009), we investigate whether there is a non linear relationship between dividend payout and ownership concentration. Table 4 reports no significant results which are not in line with those of these authors. Perhaps, this is due to the difference in the proxy of ownership concentration. In our study, we assess this variable with the sum of shareholding of the first three blockholders while they focus on the insider ownership in "very broad terms" and calculate "the total percentage of all shares owned by the members of the managerial team, both executive and non-executive board members, in addition to those owned by shareholders whose stake is over $5 \%$ of the total shares of the company". Differences in measurements likely lead to different results. Descriptive statistics relative to French firms, reported above in Table 2, highlight an average shareholding of $32.6 \%$ and $44.4 \%$ for respectively the first blockholder and the three largest shareholders. Such statistics are significantly higher than the threshold of $5 \%$ of ownership.

However, Table 4 reveals that firms with independent directors pay more dividends while those with multiple large shareholders distribute fewer dividends. Therefore, in contrast to independent directors, the controlling shareholders can collude to expropriate corporate resources and to share private benefits at the expense of minority shareholders (Pagano \& Roell, 1998; Faccio et al., 2001; Maury and Pajuste, 2002). However, independent directors contribute to enhance corporate governance efficiency and to reduce wealth expropriation. These findings are consistent with those of Sharma (2011). Table 4 reports as well the negative effect of listing French firms on a US stock exchange. Thus, French firms that are cross-listed in the US likely distribute lower dividends than those that are not cross-listed. Indeed, firms that are cross-listed abroad divulge high-quality information as they operate in a more transparent disclosure environment (Adjaoud \& Ben Amar, 2010). Given that they have less need to signal firm quality using dividends, they would pay lower dividends. With regard to financial characteristics, Table 4 shows that larger and more profitable firms with higher growth of opportunities are inclined to distribute higher dividends whereas indebted firms are reluctant to increase dividends because of financial constraints and distress. These results are in line with those of Truong and Heaney (2007) as well as Fama and French (2002). 
Table 4. The impact of ownership concentration on dividend payout

\begin{tabular}{|c|c|c|c|}
\hline & Panel (1) & Panel (2) & Panel (3) \\
\hline Intercept & $\begin{array}{c}-0.2033 \\
(-5.24 * *)\end{array}$ & $\begin{array}{c}-0.1150 \\
(-3.54 * *)\end{array}$ & $\begin{array}{c}-0.1188 \\
(-2.65 * *)\end{array}$ \\
\hline CONC & $\begin{array}{c}0.085 \\
(4.28 * *)\end{array}$ & $\begin{array}{c}0.1018 \\
\left(6.46^{* * *}\right)\end{array}$ & $\begin{array}{c}0.1410 \\
\left(2.51^{*}\right)\end{array}$ \\
\hline $\mathrm{CONC}^{2}$ & & & $\begin{array}{c}0.0151 \\
(0.21) \\
\end{array}$ \\
\hline MULT & - & $\begin{array}{c}0.07 \\
(-6.55 * * *)\end{array}$ & - \\
\hline NDIR & $\begin{array}{c}0.0427 \\
(2.35 * *)\end{array}$ & - & $\begin{array}{l}0.0385 \\
(2.21)\end{array}$ \\
\hline CRSL & $\begin{array}{l}-0.137 \\
(-8.01 * * *)\end{array}$ & $\begin{array}{c}-0.126 \\
(-7.11 * * *)\end{array}$ & $\begin{array}{c}-0.0909 \\
(-3.56 * * *)\end{array}$ \\
\hline SIZE & $\begin{array}{c}0.0334 \\
(15.29 * * *)\end{array}$ & $\begin{array}{c}0.029 \\
(15.64 * * *)\end{array}$ & $\begin{array}{c}0.031 \\
\left(14.38^{* * *}\right)\end{array}$ \\
\hline LEV & $\begin{array}{l}-0.160 \\
(-5.24 * * *)\end{array}$ & $\begin{array}{l}-0.218 \\
\left(-7.25^{* * *}\right)\end{array}$ & $\begin{array}{c}-0.1605 \\
\left(-4.63^{* * *}\right)\end{array}$ \\
\hline ROA & $\begin{array}{l}0.499 \\
\left(7.57^{* * *}\right)\end{array}$ & $\begin{array}{l}0.602 \\
(7.74 * * *)\end{array}$ & $\begin{array}{c}0.4517 \\
(5.98 * * *)\end{array}$ \\
\hline OPP & $\begin{array}{l}0.00003 \\
(0.009)\end{array}$ & $\begin{array}{l}0.00001 \\
(0.03)\end{array}$ & $\begin{array}{c}0.0001 \\
(1.06)\end{array}$ \\
\hline Industry effect & Included & Included & Included \\
\hline $\begin{array}{l}\text { Time effect } \\
\text { Adi. } \mathrm{R}^{2} \\
\mathrm{~N}\end{array}$ & $\begin{array}{l}\text { Included } \\
0.1288 \\
530\end{array}$ & $\begin{array}{l}\text { Included } \\
0.1774 \\
513\end{array}$ & $\begin{array}{l}\text { Included } \\
0.1234 \\
530\end{array}$ \\
\hline
\end{tabular}

Variable Definitions: See Table 1.

$* * *, * *, *$ respectively denote significance at $1 \%, 5 \%$, and $10 \%$ level.

\subsection{Blockholder Identity and Dividend Policy}

Table 5 summarizes empirical results relative to the influence of the identity of the first blockholder on dividend policy, namely a family shareholder (Panel 4) or an institutional investor (Panel 5). Table 5 reveals that when the largest shareholder belongs to a family group firms tend to pay lower dividends. However, when the first blockholder is an institutional investor, firms are prone to distribute higher dividends. Such findings are consistent with previous descriptive statistics already reported in Table 2.

Three main arguments might explain the negative effect of block ownership within family-controlled firms. First of all, these firms face less conflict of interest between shareholders and management although that between controlling and minority shareholders is severe. The management often belongs to the controlling family (Claessens et al., 2000) and even when the main shareholder is not involved in management; it exerts a great pressure on it (Godard \& Schatt, 2005). Family-controlled firms are hence prone to pay fewer dividends as a tool to curb agency problems. These problems are already not so acute. Secondly, family-controlled firms likely worry about future generations and the long term wealth as well as the family name (Bartholomeusz \& Tanewski, 2006). Accordingly, they would rather cut target dividend payout rates and reinvest any excess cash flow. Our results are in line with the arguments of Gugler (2003). Third, holding blocks of shares implies that portfolios are not well diversified according to modern theory of portfolio. Family shareholders are therefore more sensitive to bankruptcy risk. Given that dividends payment increases such a risk, family-controlled firms are reluctant to pay dividends.

However, Table 5 suggests that preferences of firms that are controlled by institutional investors likely tilt towards higher dividends. This finding is consistent with that of Jensen et al. (1992), Short et al. (2002) and Gugler (2003). Institutional investors are indeed believed to enhance corporate governance and to reduce the scope of rent expropriation (McConnell \& Servaes, 1990; Karpavicius \& Yu, 2012). This is namely thanks to their great material resources, sophisticated skills and extended networks (Gillan \& Starks, 2007). 
Table 5. The impact of largest shareholder identity on dividend payout

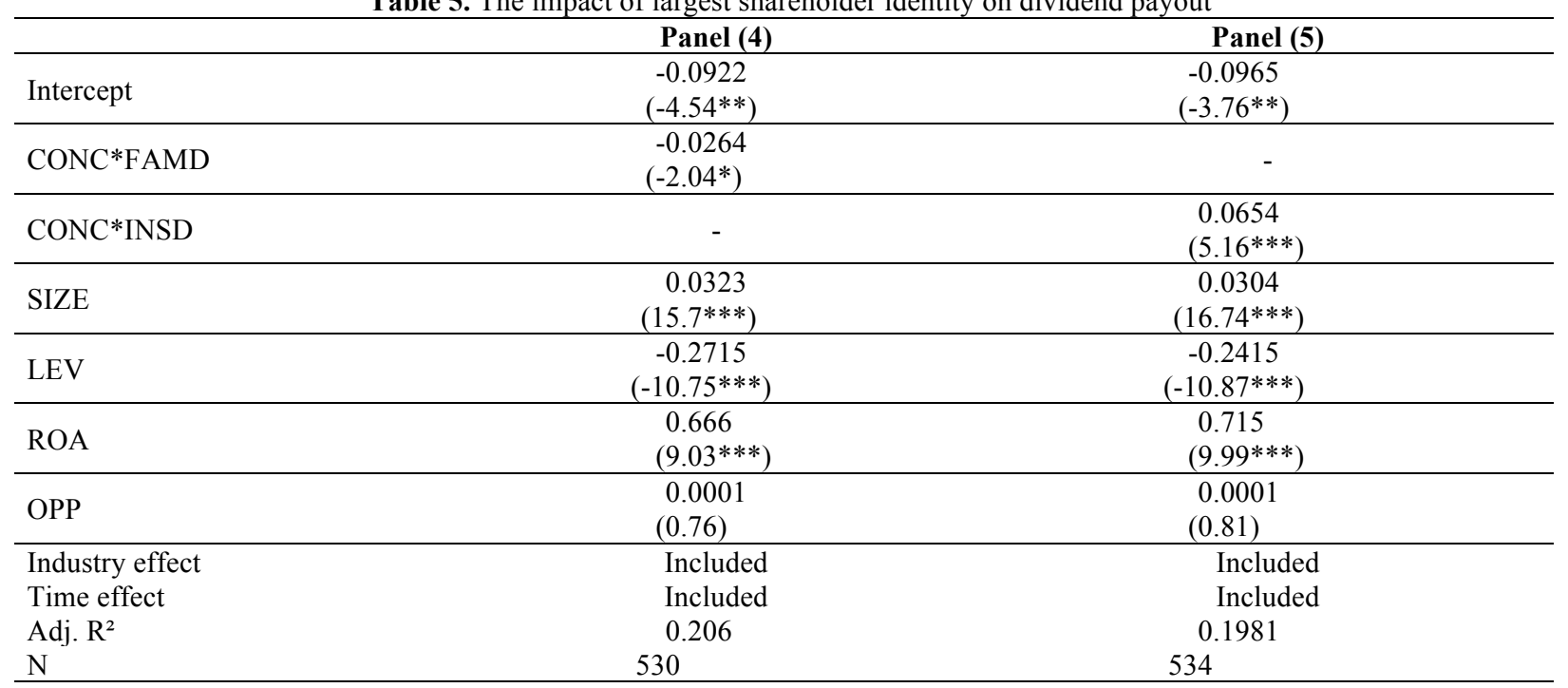

Variable Definitions: See Table 1.

$* * *, * *, *$ respectively denote significance at $1 \%, 5 \%$, and $10 \%$ level.

\subsection{Robustness Tests}

In this section, we check the robustness of our findings by investigating the relationship between dividend payout and the identity of shareholder using family (Panel 6) and institutional (Panel 7) blockholders dummy without interacting them with the concentration proxy. Table 6 recapitulates the results of this robustness test. The relative results converge with those previously reported in Table 6 as signs and significance of most variables' coefficients still remain the same. More specifically, family-controlled firms tend to pay lower dividends than their peers whose largest shareholder is an institutional investor. The latter likely distribute higher dividends. These results confirm again that institutional investors contribute to curtailing rent protection of some blockholders at the expense of minority investors, even though family blockholders do not necessarily extract and expropriate private benefits. Perhaps, family-controlled firms tend to distribute lower dividends in order to leave more cash flows at the disposal of the firm for future growth opportunities.

Table 6. The impact of largest shareholder identity on dividend payout

\begin{tabular}{lcc}
\hline & Panel (6) & Panel (7) \\
\hline \multirow{2}{*}{ Intercept } & -0.08 & -0.10125 \\
& $(-1.66)$ & $\left(-2.43^{* *}\right)$ \\
\hline \multirow{2}{*}{ FAML } & -0.0255 & - \\
\hline \multirow{2}{*}{ INST } & $\left(-2.01^{*}\right)$ & 0.03248 \\
& - & $\left(3.00^{* * *}\right)$ \\
\hline \multirow{2}{*}{ SIZE } & 0.02805 & 0.02766 \\
& $\left(9.47^{* * *}\right)$ & $(10.74 * * *)$ \\
\hline \multirow{2}{*}{ LEV } & -0.1662 & -0.166 \\
& $(-5.37 * * *)$ & $\left(-5.05^{* * *}\right)$ \\
\multirow{2}{*}{ ROA } & 0.5633 & 0.5455 \\
& $(6.97 * * *)$ & $\left(6.72^{* * *}\right)$ \\
\hline \multirow{2}{*}{ OPP } & 0.0001 & 0.0001 \\
& $(0.71)$ & $(0.88)$ \\
\hline Industry effect & Included & Included \\
Time effect & Included & Included \\
Adj. $\mathrm{R}^{2}$ & 0.1246 & 0.1328 \\
$\mathrm{~N}$ & 530 & 534 \\
\hline
\end{tabular}

Variable Definitions: See Table 1.

$* * *, * *, *$ respectively denote significance at $1 \%, 5 \%$, and $10 \%$ level.

Copyright by author(s); CC-BY 


\section{CONCLUSION AND IMPLICATIONS}

This study provides an empirical investigation of the agency theory explanation of the dividend policy in 110 French listed firms during 2006-2010. Results suggest that key determinants of dividend policy in a civil-law country such as France are not necessarily those already assumed for most common-law countries. The main objective of this paper is to investigate the influence of ownership concentration on the payout. We particularly highlight that such an influence depends on the identity of the largest shareholder.

Our study puts in evidence that shareholders afford higher dividends when the largest shareholder is an institutional investor, whereas in family-controlled firms, minority shareholders are severely expropriated and often receive lower dividends. Low levels of dividends are also reported when there are multiple large shareholders who would rather collude to expropriate corporate resources and to share private benefits rather than mutually supervise each other. Conversely, minority shareholders in firms with more independent directors might struggle against rent protection and wealth expropriation. Independent directors can improve the quality and the efficiency of corporate governance. Besides, firms that are cross-listed abroad namely in the US are required to disclose high quality information and do not need to pay higher dividends to signal firm quality.

One of the main implications of this research is that the separation of ownership and control does not help solely to explain differences in corporate decisions, for instance dividend policy. The identity of the controlling shareholder also represents a key determinant for dividend policy. Besides, this study emphasizes the urgent need to better enhance corporate governance in civil-law countries where agency conflicts are more severe between minority shareholders and blockholders rather than managers and shareholders irrespective of their origin. Therefore, traditional corporate governance mechanisms are likely inefficient to address such problems. We need other schemes to ensure an equitable treatment of shareholders and to fairly protect their rights. Furthermore, following a large bulk of research, this study overlooks one of dividend considerations that are taxation differences, as it is a very hard task to disaggregate the whole shareholding so as to disentangle the tax incentives of institutional and family investors. This might constitute an avenue for future research. We can as well extend this research by comparing the impact of the controlling family versus the dominant institutional investor before and after the crash.

\section{AUTHOR INFORMATION}

Amel Belanès is an associate Professor of Finance at High School of Economics and Trade of Tunis, University of Tunis (Tunisia). She belongs to the Research Laboratory GEF-2A Lab at the High Institute of Management of Tunis, University of Tunis (Tunisia). She has more than ten years of teaching experience. Her research interests include corporate finance, corporate governance, risk taking, dividend policy, management risk, banking industry and Islamic finance. She has published more than twenty articles in many renowned journals, namely in Journal of Applied Business Research, Markets Bankers \& Investors, Pacific Basin Finance Journal Review, Computational Economics, International Review of Finance, Afro-Asian Journal of Finance and Accounting, Management International, Journal of Emerging Market Finance, Economics and Finance Review, International Journal of Economics and Finance, Corporate Ownership and Control, Journal of Global Business Administration, etc. She is a frequent presenter in national and international conferences namely ICF - Tunisia, ATSG - Tunisia, ICEF - Turkey, CIE - Spain, AGB - USA, ACFAS - Canada, IRC- Dubai. E-mail: amel_bns@yahoo.fr

Raoudha Djebali is an assistant Professor of Accounting at High Institute of Management of Gabès, University of Sfax (Tunisia). She belongs to the Research Laboratory GEF-2A Lab at the High Institute of Management of Tunis, University of Tunis (Tunisia). Her previous studies were published in journals such as Economics and Finance Review, International Journal of Economics and Finance, etc. E-mail: djebaliraoudha@yahoo.fr 


\section{REFERENCES}

Adjaoud, F., \& and Ben Amar, W. (2010). Corporate Governance and Dividend Policy: Shareholders' Protection or Expropriation? Journal of Business Finance \& Accounting, 37, 648-667.

Amihud, Y., \& Murgia, M. (1997). Dividends, taxes, and signaling: Evidence from Germany. Journal of Finance, $52(1), 397-408$.

Barclay, M., \& Holderness, C. (1989).The private benefits from control of public corporations. Journal of Financial Economics, 25, 371-395.

Bartholomeusz, S., \& Tanewski, G.A. (2006). The relationship between family firms and corporate governance. Journal of Small Business Management, 44(2), 245-267.

Bebchuk, L., Kraakman, R., \& Triantis, G. (1999). Stock pyramids, cross-ownership, and dual class equity: The creation and agency costs of separating control from cash flow rights. NBER WP 6951.

Bena, J., \& Hanousek J. (2008). Rent extraction by large shareholders: evidence using dividend policy in the Czech Republic. Czech Journal of Economics and Finance, 58(3), 106-30.

Bhattacharya, S. (1979). Imperfect information, dividend policy and "the bird in the hand" fallacy. Bell Journal of Economics, 10, 259-270.

Boys, C. (2009). Is payout policy part of the corporate governance system? The case of France. European Journal of International Management, 3(1), 42-59.

Brockman, P. \& Unlu, E. (2009). Dividend policy, creditor rights, and the agency costs of debt. Journal of Financial Economics, 92, 276-299

Claessens S., Djankov S. \& Lang L. (2000). The separation of ownership and control in East Asian Corporations. Journal of Financial Economics, 58, 81-112.

Cronqvist, H. \& Nilsson, M. (2003). Agency costs of controlling minority shareholders. Journal of Financial and Quantitative Analysis, 38, 695-719.

De Jong, A., DeJong, D.V., Hege, U., \& Mertens, G. (2010). Leverage in pyramids: when debt leads to higher dividends, ECGI - Finance Working Paper No. 261.

Denis, D.J. \& Osobov, I. (2008). Why do firms pay dividends? International evidence on the determinants of dividend policy. Journal of Financial Economics, 89(1), 62-82.

Dyck A. \& Zingales L. (2004). Private benefits of control: an international comparison. Journal of Finance, 59, $537-$ 600 .

Easterbrook, F. (1984). Two agency-cost explanations of dividends. American Economic Review, 74, 650-659.

Faccio, M., Lang, L.H.P., \& Young, L. (2001). Dividends and expropriation. American Economic Review, 91, 5478.

Fama, E., \& French, K. (2002). Testing trade-off and pecking order predictions about dividends and debt. The Review of Financial Studies, 15, 1-33.

Farinha, J., \& De Foronda, O.L. (2009). The relation between dividends and insider ownership in different legal systems: international evidence. The European Journal of Finance, 15(2), 169-89.

Gillan, L. \& Starks L. (2007). The evolution of shareholder activism in the United States. Journal of Applied Corporate Finance, 19, 55-73.

Godard L. \& Schatt, A. (2005). Les déterminants de la qualité des conseils d'administration français, Gestion 2000, 4, 81-101.

Gomes, A. (2000). Going public with asymmetric information, agency costs, and dynamic trading, Journal of Finance, 23,303-323.

Grossman, S. \& Hart, O. (1988). One share one vote and the market for corporate control. Journal of Financial Economics, 20, 175-202.

Gugler, K. (2003). Corporate governance, dividend payout policy, and the interrelation between dividends, R\&D, and capital investment. Journal of Banking \& Finance, 27, 1297-1321.

Gugler, K., \& Yurtoglu, B. (2003). Corporate governance and dividend pay-out policy in Germany. European Economic Review, 47, 731-758.

Harada, K., \& Nguyen, P. (2011). Ownership concentration and dividend policy in Japan. Managerial Finance, 37, $362-379$.

Holderness, C.G., \& Sheehan, D.P. (1988). The role of majority shareholders in publicly held corporations. Journal of Financial Economics, 20, 317-346.

Hoshi, T., Kashyap, A., \& Scharfstein, D. (1990). The role of banks in reducing the costs of financial distress in 
Japan. Journal of Financial Economics, 27, 67-88.

Isakov, D. \& Weisskop, J.P. (2015). Pay-out policies in founding family firms. Journal of Corporate Finance, forthcoming.

Jensen, G., Solberg, D. \& Zorn, T. (1992). Simultaneous determination of insider ownership, debt, and dividend policies. Journal of Financial and Quantitative Analysis, 27, 247-263.

Jensen, M. (1986). Agency costs of free cash flow, corporate finance, and takeovers. American Economic Review, 76, 323-329.

Johnson, S., La Porta, R., Lopez-de-Silanes, F., \& Shleifer, A. (2000). Tunnelling. American Economic Review, 90, 22-27.

Kalcheva, I. \& Lin, K.V. (2007). International evidence on cash holdings and expected managerial agency problems. Review of Financial Studies, 20(4), 1087-1112.

Karpavicius, S., \& Yu, F. (2012). A test of the free cash flow hypothesis: the impact of increased institutional holdings on firm characteristics. (Social Science Research Network Working Paper).

Khan, T. (2006). Company dividends and ownership structure: Evidence from UK panel data. The Economic Journal, 116, 172-189.

La Porta, R., Lopez-de-Silanes, F., Shleifer, A., \& Vishny, R. (2000). Agency problems and dividend policies around the world. Journal of Finance, 55 (1), 1-33.

La Porta, R., Lopez-de-Silanes, F., Shleifer, A. (1999). Corporate ownership around the world. Journal of Finance, $54,471-517$.

Lintner, J. (1956). Distribution of incomes of corporations among dividends, retained earnings and taxes. American Economic Review, 46 (2), 97-113.

Maury, C.B., \& Pajuste, A. (2002). Controlling shareholders, agency problems, and dividend policy in finland. The Finnish Journal of Business Economics, 51, 15-45.

Mc Connel J.J \& Servaes, H. (1990). Additional evidence on equity ownership and corporate value. Journal of Financial Economics, 27, 595-612.

Mitton, T. (2005). Corporate governance and dividend policy in emerging markets. Emerging Markets Review, 5, 409-426.

Myers, J.S., 2000. Outside equity. Journal of Finance, 55(3), 1005-1037.

Pagano, M., \& Rôell, A. (1998). The choice of stock ownership structure: Agency costs, monitoring, and the decision to go public. Quarterly Journal of Economics, 113(1), 187-225.

Ramli, N.M. (2010). Ownership Structure and Dividend Policy: Evidence from Malaysian Companies. International Review of Business Research, 6, 170-180.

Rozeff, M. (1982). Growth, Beta, and Agency Costs as Determinants of Dividend Payout Ratios. Journal of Financial Research, 5, 249-259.

Said, H.B. (2013). Dividends and Problem of Separation of Ownership and Control: Theory and Evidence from French Firms. International Journal of Economics and Finance, 5(7), 162-177.

Sharma, V. (2011). Independent directors and the propensity to pay dividends. Journal of Corporate Finance, 17 (4), 1001-1015.

Shleifer, A., \& Vishny, R. (1997). A survey on corporate governance. Journal of Finance, 52, 737-783.

Short, H., Zhang, H. \& Keasey, K. (2002). The link between dividend policy and institutional ownership, Journal of Corporate Finance, 8 (2), 105-122.

Stulz, R.M. (1999). Globalization, corporate finance, and the cost of capital. Journal of Applied Corporate Finance, $12,8-25$.

Thomsen, S. (2005). Conflicts of interest or aligned incentives? Blockholder ownership, dividends and firm value in the US and the EU. European Business Organization Law Review, 6(2), 201-225.

Truong, T., \& Heaney, R. (2007). Largest shareholder and dividend policy around the world. The Quarterly Review of Economics and Finance, 47, 667-687.

Wang, X., David, M., \& Scott, W. (2011). The impact of government ownership on dividend policy in China. Advances in Accounting, 27(2), 366-372.

Warther, V. (1993). Boards, dividends, and sleeping dogs, Graduate School of Business. University of Chicago: Chicago.

Zwiebel, J. (1996). Dynamic Capital Structure under Managerial Entrenchment. American Economic Review, 86, 1197-1215. 


\section{NOTES}

